\title{
Bioremediation of Petroleum Hydrocarbons in Crude Oil Contaminated Soil from Wonocolo Public Oilfields using Aerobic Composting with Yard Waste and Rumen Residue Amendments
}

\author{
Gina L. Sari ${ }^{* 1}$, Yulinah Trihadiningrum ${ }^{2}$, Ni'matuzahroh ${ }^{3}$ \\ ${ }^{1}$ Faculty of Engineering, Universitas Singaperbangsa Karawang, Teluk Jambe Timur, \\ Karawang 41361, Indonesia \\ e-mail: ginalovasari@gmail.com \\ ${ }^{2}$ Department of Environmental Engineering, Faculty of Civil, Environmental and Geo Engineering, \\ Institut Teknologi Sepuluh Nopember, Surabaya 60111, Indonesia \\ e-mail: trihadiningrum@gmail.com \\ ${ }^{3}$ Department of Biology, Faculty of Science and Technology, Airlangga University, \\ Surabaya 60111, Indonesia \\ e-mail: nimatuzahroh@yahoo.com
}

Cite as: Sari, G. L., Trihadiningrum, Y., Ni'matuzahroh, Bioremediation of Petroleum Hydrocarbons in Crude Oil Contaminated Soil from Wonocolo Public Oilfields using Aerobic Composting with Yard Waste and Rumen Residue Amendments, J. sustain. dev. energy water environ. syst., 7(3), pp 482-492, 2019, DOI: https://doi.org/10.13044/j.sdewes.d7.0262

\begin{abstract}
The efficiency of composting method with yard waste and rumen residue amendments to reduce soil pollution by total petroleum hydrocarbon in Wonocolo public oilfields was investigated in the laboratory scale for 150 days. Crude oil contaminated soil was mixed with yard waste and rumen residue mixture at 1:1 ratio then composted in 2 replicates. Pure crude oil contaminated soil was composted in parallel. The results showed that total petroleum hydrocarbon degradation efficiency of soils amended with yard waste and rumen residue mixture was 31 times higher than contaminated soil, which fulfilled the soil quality standard $(6,974.58 \mathrm{mg} / \mathrm{kg})$. The degradation of total petroleum hydrocarbon might be performed by Bacillus sp., and Bacillus cereus as the dominant bacteria at the end of composting process. These results showed that yard waste and rumen residue transformation could accelerate the degradation of aliphatic and aromatic fractions of petroleum hydrocarbon in crude oil contaminated soil. Both of these wastes are generally easy to obtain around Wonocolo public oilfield and highly recommended to use as the main substrate in the composting process.
\end{abstract}

\section{KEYWORDS}

Petroleum hydrocarbon degradation, Composting, Bacillus sp., Bacillus cereus, Wonocolo public oilfields.

\section{INTRODUCTION}

Wonocolo public oilfields, which inadequately operated since 1942, was one of the crude oil sources in Indonesia [1]. The spills of crude oil from exploitation activities such as drilling, transportation, and refining caused soil pollution by Total Petroleum Hydrocarbon

\footnotetext{
* Corresponding author
} 
(TPH). As reported by Handrianto et al. [1], the TPH concentration in soil at Wonocolo public oilfields was $41,200 \mathrm{mg} / \mathrm{kg}$ which exceeded the quality standards of $10,000 \mathrm{mg} / \mathrm{kg}$ in Indonesia [2], Texas, Lousiana, Colorado, and Michigan [3]. Our previous study also confirmed that the topsoil of transportation, refining, and old well area at Wonocolo public oilfields were highly polluted by TPH of 52,328, 76,752 and 107,189 mg/kg, respectively [4]. There also have been found soil contamination by lead $(\mathrm{Pb})$, chromium $(\mathrm{Cr})$, and mercury $(\mathrm{Hg})$ in the ranged of $0.07-0.10,0.02-0.03$, and $0.05-0.06 \mathrm{mg} / \mathrm{g}$, respectively [5].

Agency for Toxic Substances and Disease Registry (ASTDR) [6] and Indonesian Government Regulation No. 101 [7] stated that TPH polluted soil was categorized as hazardous waste, classified as prioritized pollutant. TPH are toxic, mutagenic, and carcinogenic compounds [8] which consist of aliphatic and aromatic hydrocarbons [6]. Both of these hydrocarbons could harm living things through protein synthesis process and membrane plasma system damage [9], then lead to gene mutation [10]. For humans, TPH exposure could be through dermal contact and inhalation system because its semi-volatile compounds [11]. Furthermore, Das and Chandran [12] stated that TPH is recalcitrant and hardly degraded by bacteria which is influenced by its atomic structure [13] and low solubility [14]. It makes TPH potentially accumulate in the environment [15]. To minimize the risks to local communities and environment, soil remediation was required to remove TPH in the soil.

Indonesian Ministry of Environment Decree No. 128 [2] suggested biological methods for soil remediation which polluted less than $150,000 \mathrm{mg} / \mathrm{kg}$ of TPH. Biological methods utilized microbial co-metabolism to breakdown and transform TPH into innocuous substances. The co-metabolism capability could be optimized by stimulating the growth of indigenous microorganisms through providing suitable nutrients, air supply, $\mathrm{pH}$, and moisture applied in composting technique [11]. The composting process, known as the easiest and most cost-effective method to treat TPH [16], could be conducted by mixing the polluted soil with compost-making materials as the main nutrient source [17]. The difference of compost-making materials may affect the effectiveness of TPH removal in polluted soil.

$\mathrm{Xu}$ and Liu [18] reported that peanut hull powder amendments could eliminate $38.00 \%$ of TPH in crude oil contaminated soil composting process for 84 days. Omosiowho et al. [19] reported that grass and wood chips could degrade $66.54 \%$ of TPH for 35 days of composting process. Qin et al. [20] also reported that biochar from wheat straw utilization as the main nutrient might reduce $77.80-84.80 \%$ of TPH during 180 days composting process. Furthermore, polluted soil in Wonocolo public oilfield has been composted by Handrianto et al. [1] using peanut shell compost for 30 days and could reduce the TPH content up to $66.80 \%$. However, the usage of peanut shell compost in composting process of TPH polluted soil is less effective for field application due to its limitations.

The aim of this study is to investigate the feasibility of yard waste and rumen residue mixture as nutrient sources in composting process to remove TPH in polluted soil. In this study, we also identify the degraded fractions of TPH and dominant bacteria in composting process using both of organic waste. In addition, yard waste and rumen residue utilization are expected to solve the high production of organic waste in Indonesia.

\section{METHODS}

Crude oil contaminated soil and organic waste were used as raw materials in this research. During the research, physicochemical properties of composting were periodically analyzed. 


\section{Contaminated soil}

The crude oil contaminated soil was obtained from Wonocolo public crude oilfields. Thirty-eight samples were taken from 0-30 depth from old wells, transportation line, and refinery area with different patterns of diagonal, random, and line, respectively. The samples were mixed and filtered using $2 \mathrm{~mm}$ sieves to obtain a homogenous composite sample, then stored at $4{ }^{\circ} \mathrm{C}$ [21]. Soil texture was identified as silty-clay loam ( $25 \%$ clay, $56 \%$ silt, and $20 \%$ sand) according to USDA classification using hydrometer method [22].

\section{Organic waste}

The organic waste was prepared by mixing yard waste and rumen residue in a ratio of 3:1 (Y/R) to fulfill the composting nutrient requirements $[1,23]$. Both of organic wastes were shredded and sieved into $5 \mathrm{~mm}$ size before mixing. The $\mathrm{C} / \mathrm{N}$ ratio, moisture, and $\mathrm{pH}$ of the organic waste were $29.96,62.50 \%$ and 5.00, respectively. The initial concentration of TPH was $2,153.33 \mathrm{mg} / \mathrm{kg}$, and bacterial population was $1.76 \times 10^{10} \mathrm{CFU} / \mathrm{g}$.

\section{Composting experiments}

The composting process was conducted in laboratory scale experiment for 150 days. About $1.00 \mathrm{~kg}$ Contaminated Soil (CS) and soil-YR mixture, S/YR (1:1 ratio), were placed in glass reactor of $3.50 \mathrm{~L}$ volume capacity. The composting was performed at existing temperature and $\mathrm{pH}$ which were measured daily (thermometer) and every 3 days (Takemura soil tester), respectively. Furthermore, the composting process was conducted under aerobic condition through manual agitation every 3 days to allow good aeration and homogenization. Moisture was maintained in optimal value of 50-60\% [24, 25] during the composting period. This experiment was implemented with two replications. Compost samples were collected on day $0,20,40,60,80,100,120$, and 150 to be analysed.

\section{Carbon and nitrogen ratio analysis}

The carbon and nitrogen $(\mathrm{C} / \mathrm{N})$ ratio were calculated based on organic carbon with total nitrogen content. Organic carbon and total nitrogen content were analyzed using Walkley and Black [26] and Kjehdahl [27] method, respectively.

\section{Bacterial enumeration and identification}

The determination of heterotrophic bacteria population was performed by serial dilution of compost samples using $0.90 \% \mathrm{NaCl}$, then plated on nutrient agar medium. The bacteria population was counted after incubation at room temperature for 24 hours, and the results were expressed as Colony-Forming Units (CFU) per gram. Furthermore, dominant colonies were isolated and streaked into nutrient agar medium for bacterial strain characterization and identification [28]. Morphological and physiological characteristics were observed using microscope, Gram staining [29], and Microbact Identification Kits (Microbact ${ }^{\mathrm{TM}}$ GNB12A and 12B). Identification of bacterial strain was conducted following Bergey's Manual of Determinative Bacteriology [30].

\section{Total Petroleum Hydrocarbon analysis}

The changes of TPH in crude oil contaminated soil were observed on $0^{\text {th }}$ and $150^{\text {th }}$ day of composting. The samples were extracted using conventional Soxhlet extraction and Gravimetric method following APHA-AWWA and WEF standard No. 5520D and 5520F [31], respectively. Quantification of TPH in the extract was done by Fourier Transform Infrared spectroscopy (FT-IR). The FT-IR was performed using Thermo Scientific ${ }^{\mathrm{TM}}$ Nicolet iS5 at 2,930 $\mathrm{cm}^{-1}$ absorbance according to ASTM D7066-4 with $0.1 \mu \mathrm{L}$ injection volume of $\mathrm{TPH}$ extract [32]. The fractions of $\mathrm{TPH}$ were measured by Gas 
Chromatography-Mass Spectrometry (GC-MS), using Agilent HP 1 MS column. Chromatographic resolution was achieved by a $30 \mathrm{~m} \times 0.25 \mathrm{~mm}$ capillary column with a $0.25 \mu \mathrm{m}$ film thickness. The carrier gas was helium at a flow rate of $3 \mathrm{~mL} / \mathrm{min} .0 .1 \mu \mathrm{L}$ TPH extract was injected to GC-MS with analytical conditions, such as initial temperature $60{ }^{\circ} \mathrm{C}$ with isothermal operation for $5 \mathrm{~min}$, heated to final temperature of $280{ }^{\circ} \mathrm{C}$ at a constant rate of $5{ }^{\circ} \mathrm{C} \mathrm{min}{ }^{-1}$ with a $71 \mathrm{~min}$ isothermal. The measurement was conducted by internal calibration method, and TPH analysis was performed by comparing their peaks standards. The TPH concentration was expressed in $\mathrm{mg} / \mathrm{kg}$.

\section{RESULTS AND DISCUSSION}

The physicochemical properties of composting process fluctuated during 150 days which indicates bacterial activity. It affects the bioremediation effectiveness considering that bacteria are the primary degrader of TPH.

\section{Characteristics of raw material}

The initial concentration of $\mathrm{TPH}$, moisture, $\mathrm{pH}$, and $\mathrm{C} / \mathrm{N}$ ratio for $\mathrm{CS}$ were $51,083.04 \mathrm{mg} / \mathrm{kg}, 50.00,7.00$ and 23.37 , respectively. The $\mathrm{C} / \mathrm{N}$ ratio of CS indicated that crude oil contaminated soil was reasonable for composting process, which the criteria was ranged from 15-30 [33]. There was also $4.26 \times 10^{7} \mathrm{CFU} / \mathrm{g}$ of indigenous bacterial population in soil. Meanwhile, the S/YR values were $27,743.57 \mathrm{mg} / \mathrm{kg}, 58.00 \%, 5.20$, $34.40,3.03 \times 10^{10} \mathrm{CFU} / \mathrm{g}$ for initial concentration of $\mathrm{TPH}$, moisture, $\mathrm{pH}, \mathrm{C} / \mathrm{N}$ ratio, and bacterial population, respectively. The $\mathrm{pH}$ value of $\mathrm{S} / \mathrm{YR}$ was lower than $\mathrm{CS}$, it might influence by the $\mathrm{pH}$ of organic waste $[33,34]$. Moreover, organic waste amendments led to $\mathrm{C} / \mathrm{N}$ ratio and bacterial population increasing which indicated that it could act as nutrient and exogenous bacteria sources $[33,35]$. The $\mathrm{C} / \mathrm{N}$ ratio of $\mathrm{S} / \mathrm{YR}$ was close to Zhang et al. [18] criteria value for contaminated soil composting of 25-40.

\section{Composting process}

Moisture content, temperature, $\mathrm{pH}, \mathrm{C} / \mathrm{N}$ ratio, and bacterial population showed fluctuating values during 150 days of crude oil contaminated soil composting process. The values of these parameters in this experiment was expressed in the mean of two replicates. Figure 1a showed that the composting of CS and S/YR were carried out in maintained condition of moisture content (50.00 to 60.00\%) to ensure the process worked well [36].

During composting process, temperature in CS showed almost similar values to those of the ambient temperature values $\left(31.28-33.50{ }^{\circ} \mathrm{C}\right)$ which was lower than $\mathrm{S} / \mathrm{YR}$ (Figure $1 \mathrm{~b}$ ). The temperature of S/YR was increased in the $10^{\text {th }}$ first day of composting process from 34.50 to $35.05^{\circ} \mathrm{C}$. Then, it showed similar trend of changes with CS which was decreased up to day $30^{\text {th }}\left(31.70{ }^{\circ} \mathrm{C}\right)$ of composting process. On day $40^{\text {th }}$, the temperature was increased $\left(33.03{ }^{\circ} \mathrm{C}\right)$, then decreased at $50^{\text {th }}\left(32.38{ }^{\circ} \mathrm{C}\right)$, and slightly increased following ambient temperature from $60^{\text {th }}$ up to the end of composting process (33.13-33.25 $\left.{ }^{\circ} \mathrm{C}\right)$.

The increased temperature indicated that organic substrate decomposition by microbial microorganism which produced heat energy, was high [25, 37]. It might lead to TPH degradation in contaminated soil, to occur at the same time. It is related to S/YR pH value decreasing from day $30^{\text {th }}$ to $45^{\text {th }}$ of composting process (Figure 1c), which due to the accumulation of organic acids from organic substrate hydrolysis [25]. Then, the organic acids were decomposed into $\mathrm{CO}_{2}$ and $\mathrm{H}_{2} \mathrm{O}$, which made its availability low. This caused the $\mathrm{pH}$ to increase to 6.66 and it remained stable in the range of 6.82-6.94 until the end of the process. It also caused the $\mathrm{pH}$ value of $\mathrm{CS}$ to range in neutral values (6.85-7.00) from day $0^{\text {th }}$ to $150^{\text {th }}$ composting process. 


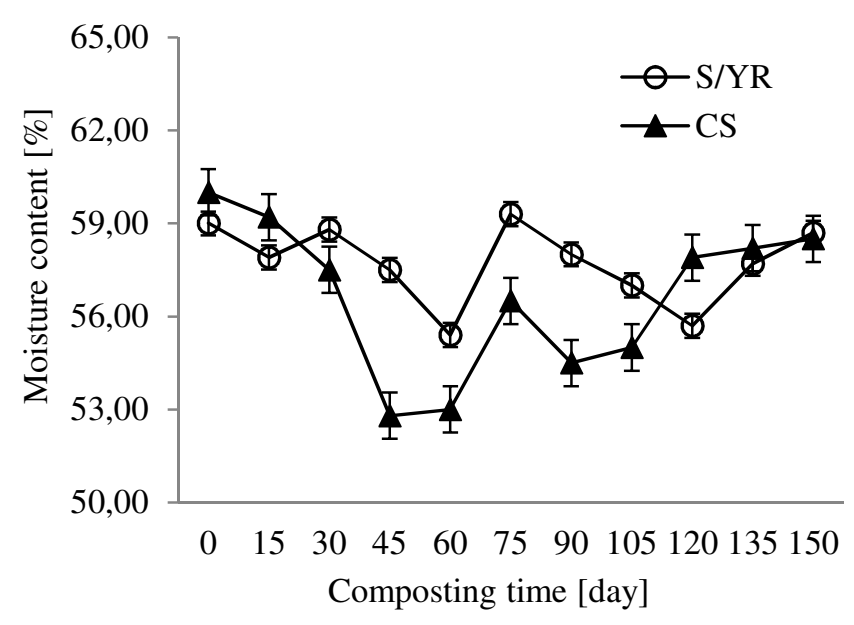

(a)

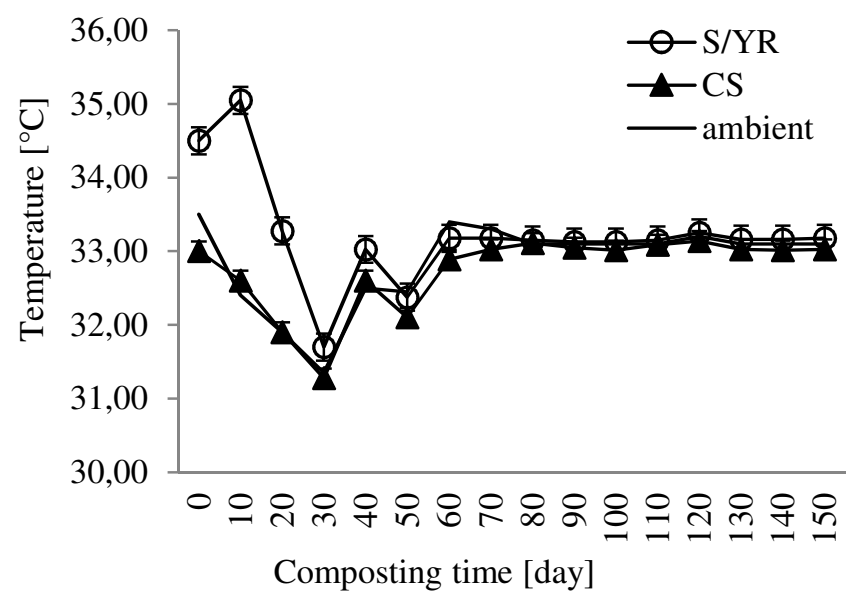

(b)

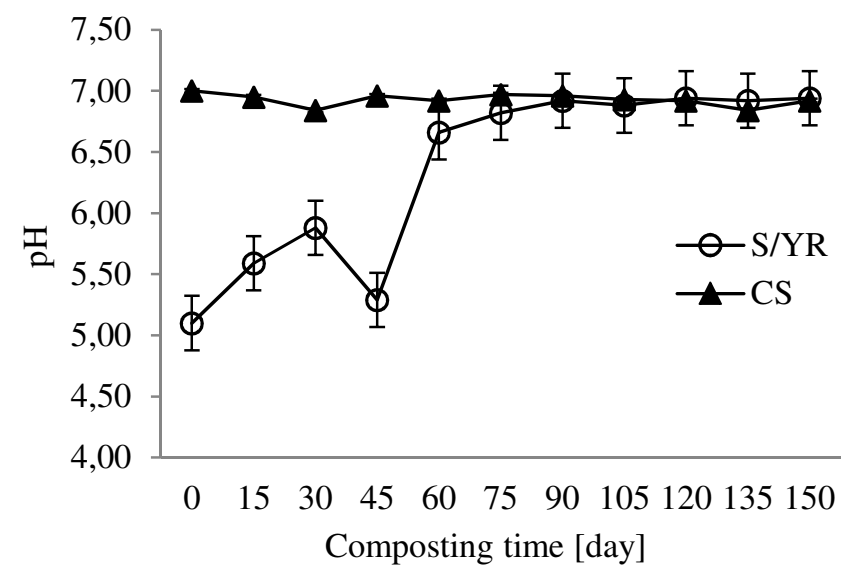

(c)

Figure 1. The changes of moisture content, temperature, and $\mathrm{pH}$

\section{Carbon and nitrogen ratio and bacterial population during composting process}

The $\mathrm{C} / \mathrm{N}$ ratio values of $\mathrm{CS}$ and S/YR declined from 23.37 and 34.40 to 3.76 and 13.29 at the end of composting process, respectively (Figure 2). Prior to declining, the $\mathrm{C} / \mathrm{N}$ ratio values of $\mathrm{CS}$ reactor were slightly increased from day $0^{\text {th }}(23.37)$ to $30^{\text {th }}(26.02)$ 
of composting period. It might be caused by high release of nitrogen under anoxic-anaerobic conditions, which might occur due to inadequate mixing of air supply during the process.

The decrease of $\mathrm{C} / \mathrm{N}$ ratio was caused by the occurrence of microbial mineralization. Declined $\mathrm{C} / \mathrm{N}$ ratio value of $\mathrm{S} / \mathrm{YR}$ was three times higher than $\mathrm{CS}$, which showed carbon utilization of organic waste as energy source was high [34]. It was expressed by a slightly increased of S/YR bacterial population from initial $\left(3.03 \times 10^{10} \mathrm{CFU} / \mathrm{g}\right)$ to $120^{\text {th }}$ day $\left(1.02 \times 10^{21} \mathrm{CFU} / \mathrm{g}\right)$ on S/YR. This may be related to the adapted (lag phase) and growth (log phase) ability of heterotrophic bacterial from organic waste with the TPH presence in the mixture. At the end of S/YR composting process, the bacterial population declined to $7.28 \times 10^{19} \mathrm{CFU} / \mathrm{g}$ reflecting the occurrence of maturation phase. Meanwhile, CS bacterial population was in the $\log$ phase from day $0^{\text {th }}$ to $150^{\text {th }}$ which increased from $4.26 \times 10^{7}$ to $6.89 \times 10^{19} \mathrm{CFU} / \mathrm{g}$, respectively. It indicates that substrate availability was still sufficient for bacterial growth, shown by high $\mathrm{C} / \mathrm{N}$ ratio at the end of the composting process.

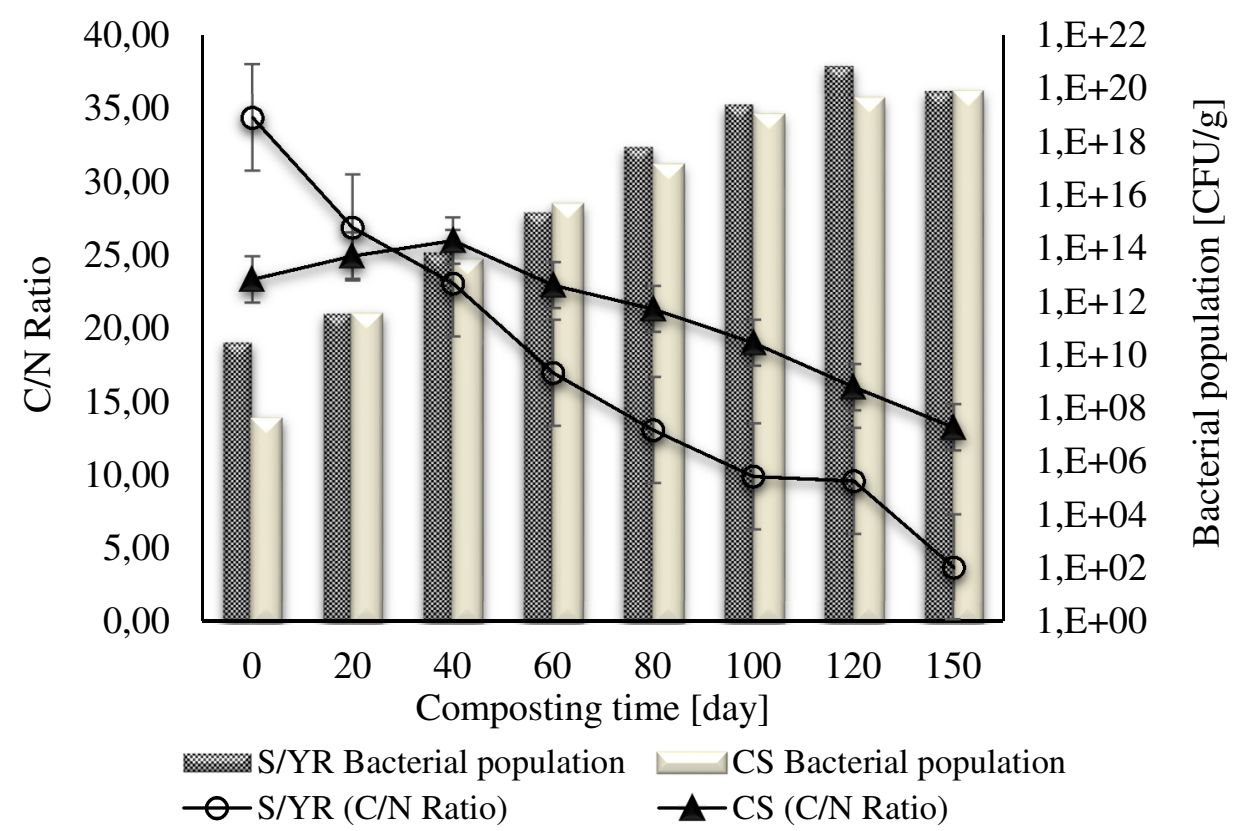

Figure 2. The changes of $\mathrm{C} / \mathrm{N}$ ratio and bacterial population

\section{Total Petroleum Hydrocarbon removal during composting process}

The concentration of aliphatic and aromatic petroleum hydrocarbon (TPH) before and after $150^{\text {th }}$ days composting is listed in Table 1 . The addition of YR mixture into polluted soil could reduce the initial TPH level from $51,083.04$ to $27,743.57 \mathrm{mg} / \mathrm{kg}$, which eases bacteria load to reduce TPH.

After the treatment, TPH concentration on S/YR was $6,974.58 \mathrm{mg} / \mathrm{kg}$ and fulfilled soil quality standard of $10,000 \mathrm{mg} / \mathrm{kg}$. The $\mathrm{S} / \mathrm{YR}$ treatment showed higher TPH removal than CS in average of $20,768.99 \mathrm{mg} / \mathrm{kg}(74.86 \%)$ and $1,205.67 \mathrm{mg} / \mathrm{kg}(2.36 \%)$, respectively. This is due to the intense microbial activity in S/YR composting process, which was shown by higher population than CS. It was also related to high temperature achievement and $\mathrm{pH}$ values fluctuation.

The biodegradable substrate in organic waste provided an opportunity for bacteria to adapt and grow simultaneously, while also producing required biosurfactant to improve TPH bioavailability for them [38]. The increasing of TPH bioavailability was also assisted by the presence of compost Humic Acid Like (cHAL) which was formed in 
humification process and had surfactant like-ability [39, 40]. Furthermore, that process could lead to greater TPH catabolic activity of indigenous bacteria in crude oil contaminated soil [41]. This was the reason for low TPH degradation in CS composting, although the bacterial population was similar to S/YR.

Table 1. TPH concentrations during composting process

\begin{tabular}{|c|c|c|c|c|c|c|}
\hline \multirow{3}{*}{ TPH fraction } & \multicolumn{6}{|c|}{ Concentration $[\mathrm{mg} / \mathrm{kg}]$} \\
\hline & \multicolumn{3}{|c|}{ CS } & \multicolumn{3}{|c|}{ S/YR } \\
\hline & Initial & 150 days & Removal [\%] & Initial & 150 days & Removal [\%] \\
\hline \multicolumn{7}{|c|}{ Aliphatic hydrocarbon } \\
\hline $\mathrm{C}_{5-8}$ & 0.00 & $2,657.90$ & 0.00 & $1,538.53$ & $1,494.95$ & 2.83 \\
\hline $\mathrm{C}_{9-12}$ & $1,282.07$ & 92.25 & 92.80 & 0.00 & 0.00 & 0.00 \\
\hline $\mathrm{C}_{13-16}$ & $11,133.41$ & 887.89 & 92.03 & $3,277.23$ & $2,800.16$ & 14.56 \\
\hline $\mathrm{C}_{17-20}$ & $32,735.00$ & $30,263.13$ & 7.55 & $19,151.50$ & 741.55 & 96.13 \\
\hline $\mathrm{C}_{21-24}$ & 453.56 & $10,821.85$ & 0.00 & $1,618.60$ & $1,937.93$ & 0.00 \\
\hline $\mathrm{C}_{25-28}$ & $3,084.21$ & $5,154.36$ & 0.00 & 734.95 & 0.00 & 100.00 \\
\hline \multicolumn{7}{|c|}{ Aromatic hydrocarbon } \\
\hline $\mathrm{C}_{5-8}$ & 0.00 & 0.00 & 0.00 & 397.50 & 0.00 & 100.00 \\
\hline $\mathrm{C}_{9-12}$ & $2,394.80$ & 0.00 & 100.00 & $1,025.26$ & 0.00 & 100.00 \\
\hline $\mathrm{C}_{13-17}$ & 0.00 & 0.00 & 0.00 & 0.00 & 0.00 & 0.00 \\
\hline Total & $51,083.04$ & $49,877.37$ & 2.36 & $27,743.57$ & $6,974.58$ & 74.86 \\
\hline
\end{tabular}

The occurrence of high TPH degradation was also caused by higher solubility of aliphatic $\left(\mathrm{C}_{5-28}\right)$ and aromatic $\left(\mathrm{C}_{5-17}\right)$ hydrocarbon in samples than other complex TPH fractions of 0.65-5.80 and 0.03 mg/L [6], respectively. During S/YR composting process, the dominance of TPH fraction degradation was found at $\mathrm{C}_{17-20}$ aliphatic and $\mathrm{C}_{9-12}$ aromatic hydrocarbons of $18,409.96 \mathrm{mg} / \mathrm{kg}(96.13 \%)$ and $1,025.26 \mathrm{mg} / \mathrm{kg}(100.00 \%)$, respectively. For CS, the dominant degraded fractions were $\mathrm{C}_{13-16}$ aliphatic $(10,245.52 \mathrm{mg} / \mathrm{kg}, 92.03 \%)$ and $\mathrm{C}_{9-12}$ aromatic $(2,394.80 \mathrm{mg} / \mathrm{kg}, 100 \%)$. In contrast, $\mathrm{C}_{5-8}$ and $\mathrm{C}_{21-28}$ concentrations of aliphatic fraction were increases. This may be due to the accumulation of decomposed aromatic fractions, because it was completely removed at the end of the process.

Compared to the previous research, highest TPH removal in this study $(20,768.99 \mathrm{mg} / \mathrm{kg}, 74.86 \%)$ was lower than the research conducted by Handrianto et al. [1], who composted crude oil contaminated soil from Wonocolo oilfields using peanut (Arachishypogaea L.) compost for 30 days $(21,090-27,532 \mathrm{mg} / \mathrm{kg}, 51.20-66.80 \%)$. Peanut composting was conducted by adding livestock dung, husks, molasses, and EM4 as stimulant. This suggested that rumen residue and yard waste were favorable bulking agent to be added in the treatment of crude oil contaminated soil in Wonocolo oilfields, though it took a longer time.

The difference in bioremediation efficiency of each study was significantly influenced by environmental factors such as temperature, $\mathrm{pH}$, moisture content, $\mathrm{C} / \mathrm{N}$ ratio, air supply, particle size, and incubation time $[12,21]$. In addition, the TPH fraction in crude oil contaminated soil also affected the degradation efficiency which referred to its hydrophobicity [42].

\section{Dominant bacteria during composting process}

At the end of composting process, three and two dominant bacteria colonies from S/YR and CS, respectively, were isolated. Morphological (Table 2) and physiological (Table 3) characteristics of isolated colonies belonged to Bacillus genera [43]. The characteristics and the prediction following Bergey's Manual of Determinative Bacteriology of S/YR confirmed that the colonies belong to Bacillus sp. (73.68\%), Bacillus pantothenticus $(75.00 \%)$, and Bacillus cereus $(82.00 \%)$. For CS, the colonies were Bacillus sp. (72.00\%) and Bacillus cereus $(77.00 \%)$. 
Table 2. Morphological characteristics of isolated colony

\begin{tabular}{|c|c|c|c|c|c|}
\hline \multirow{2}{*}{ Bacteria colony } & \multicolumn{5}{|c|}{ Morphological characteristics } \\
\hline & Color & Shape & Edge & Size $[\mathrm{cm}]$ & Gram strain \\
\hline S/YR $1^{\text {st }}$ colony/Bacillus sp. & White & Irregular & Undulate & 0.50 & + \\
\hline S/YR $2^{\text {nd }}$ colony/Bacillus pantothenticus & White & Irregular & Lobate & 4.00 & + \\
\hline S/YR $3^{\text {rd }}$ colony/Bacillus cereus & Cream & Circular & Entire & 0.40 & + \\
\hline CS $1^{\text {st }}$ colony/Bacillus $s p$. & White & Irregular & Undulate & 4.50 & + \\
\hline CS $2^{\text {nd }}$ colony/Bacillus cereus & White & Circular & Filiform & 0.10 & + \\
\hline
\end{tabular}

Bacillus sp., and Bacillus cereus were confirmed as hydrocarbon-degrading bacteria by Prakash et al. [44] and Cerqueira et al. [45]. Both bacteria might be responsible for TPH removal in composting process [26]. Bacillus sp., was capable to remove naphthalene and pyrene [44, 45]. Similar capabilities were shown by Bacillus cereus, which was able to degrade TPH [46], naphthalene [47], and benzene [48]. Meanwhile, Bacillus pantothenticus was a protease producer [49] that might act as organic substrate decomposer. However, its ability to degrade hydrocarbon was unknown until now.

Table 3. Physiological characteristics of isolated colony

\begin{tabular}{|c|c|c|c|c|c|c|c|c|c|c|c|c|c|c|c|}
\hline \multirow[b]{2}{*}{ Bacteria } & \multicolumn{15}{|c|}{ Biochemical characteristics } \\
\hline & $\stackrel{?}{:}$ & 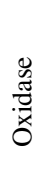 & 莺 & 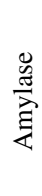 & U & 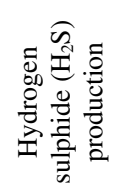 & 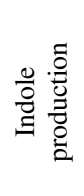 & 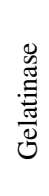 & 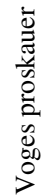 & 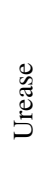 & 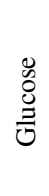 & 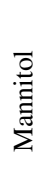 & $\frac{0}{0}$ & 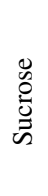 & 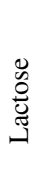 \\
\hline $\begin{array}{l}\text { S/YR } 1^{\text {st }} \text { colony/ } \\
\text { Bacillus sp. }\end{array}$ & + & + & + & + & + & - & - & - & + & - & - & - & - & - & - \\
\hline $\begin{array}{l}\mathrm{S} / \mathrm{YR} 2^{\text {nd }} \text { colony/ } \\
\text { Bacillus } \\
\text { pantothenticus }\end{array}$ & + & + & - & - & + & - & - & - & + & - & - & - & - & - & - \\
\hline $\begin{array}{l}\mathrm{S} / \mathrm{YR} 3^{\text {rd }} \text { colony/ } \\
\text { Bacillus cereus }\end{array}$ & + & + & + & + & + & - & - & - & + & - & - & - & - & - & - \\
\hline $\begin{array}{l}\text { CS } 1^{\text {st }} \text { colony/ } \\
\text { Bacillus sp. }\end{array}$ & + & + & + & - & + & - & - & + & + & - & - & - & - & - & - \\
\hline $\begin{array}{l}\mathrm{CS} 2^{\text {nd }} \text { colony/ } \\
\text { Bacillus cereus }\end{array}$ & + & + & + & + & + & - & - & - & + & - & - & - & - & - & - \\
\hline
\end{tabular}

\section{CONCLUSION}

Rumen residue and yard waste amendments play an important role to increase the TPH removal efficiency (74.68\%) during 150 days of composting process. TPH concentration at $150^{\text {th }}$ day of composting meets the contaminated soil quality standard of $10,000 \mathrm{mg} / \mathrm{kg}$. The degradation of TPH carried out by Bacillus sp., and Bacillus cereus, where the highest level found in $\mathrm{C}_{13-20}$ of aliphatic fraction.

\section{ACKNOWLEDGEMENT}

The authors gratefully acknowledge the Indonesian Ministry of Research, Technology, and Higher Education for the Doctoral Dissertation Research Grant, which made this study to work out. We also thank Mrs. Mery M. Soesilo, Mrs. Hurun In, and Ms. Kartika Primasari at Solid Waste Laboratory of Institut Teknologi Sepuluh Nopember and Biology Laboratory of Airlangga University for their scientific contribution and assistance in sample analysis.

\section{REFERENCES}

1. Handrianto, P., Rahayu, Y. S. and Yuliani, Y., The Bioremediation as Solution of Hydrocarbon Contaminated Soil (in Indonesian), Proceedings of the Chemical National Conference, Surabaya, Indonesia, pp 22-30, February 25, 2012. 
2. Indonesian Environment Ministry Decree No. 128, Procedures and Technical Requirements of Biological Treatment for Oil and Earth Wastewater Contaminated by Petroleum, Ministry of Environment, Jakarta, Indonesia, 2003.

3. Hamilton, W. A. and Sewell, H. J., Technical Basis for Current Soil Management Level of Total Petroleum Hydrocarbons, Proceedings of $6^{\text {th }}$ Annual International Petroleum Environmental Conference, Houston, Texas, USA, pp 1-13, November 16-18, 1999.

4. Sari, G. L., Trihadiningrum, Y. and Ni'matuzahroh, Petroleum Hydrocarbon Pollution in Soil and Surface Water by Public Oil Fields in Wonocolo Sub-district, Indonesia, J. Ecol. Eng., Vol. 19, No. 2, pp 184-193, 2018, https://doi.org/10.12911/22998993/82800

5. Sari, G. L., Trihadiningrum, Y., Suci, F. C. and Hadining, A. F., Identification of Total Petroleum Hydrocarbon and Heavy Metals Levels in Crude Oil Contaminated Soil at Wonocolo Public Mining, Environment Asia, Vol. 11, No. 2, pp 109-117, 2018, https://doi.org/10.14456/ea.2018.26

6. Agency for Toxic Substances and Disease Registry (ATSDR), Toxicological Profile for Total Petroleum Hydrocarbons (TPH), U.S. Department of Health and Human Services, Public Health Service, Atlanta, Georgia, USA, 1999.

7. Indonesian Government Regulation No. 101, Hazardous Waste Management (in Indonesian), Jakarta, Indonesia, 2014.

8. Liu, J., Liu, G., Zhang, J., Yin, H. and Wang, R., Occurrence and Risk Assessment of Polycyclic Aromatic Hydrocarbons in Soil from the Tiefa Coal Mine District, Liaoning, China, J. Environ. Monit., Vol. 14, No. 10, pp 2634-2642, 2012, https://doi.org/10.1039/C2EM30433C

9. Ezeonu, C. S., Onwurah, I. N. E. and Oje, O. A., Comprehensive Perspective in Bioremediation of Crude Oil Contaminated Environments, https://www.intechopen.com/books/introduction-to-enhanced-oil-recovery-eor-process es-and-bioremediation-of-oil-contaminated-sites/comprehensive-perspective-in-biorem ediation-of-crude-oil-contaminated-environments, [Accessed: 01-February-2018]

10. Okop, I. J., Bassey, C. E. and Okorie, F. S., Chemometric Determination of Chemical and Physical Assortment of Total Hydrocarbons Within Crude Oil Spilled Soil, Int. Res. J. Nat. Sci., Vol. 1, No. 2, pp 23-33, 2013.

11. Park, I.-S. and Park, J.-W., A Novel Total Petroleum Hydrocarbon Fractionation Strategy for Human Health Risk Assessment for Petroleum Hydrocarbon-Contaminated Site Management, J. Hazard. Mater., Vol. 179, No. 1-3, pp 1128-1135, 2010, https://doi.org/10.1016/j.jhazmat.2010.03.124

12. Das, N. and Chandran, P., Microbial Degradation of Petroleum Hydrocarbon Contaminants: An Overview, Biotech. Res. Inter., Vol. 2011, pp 1-13, 2011, https://doi.org/10.4061/2011/941810

13. Chorom, M. and Hosseini, S. S., Bioremediation of Crude Oil-Polluted Soil by Sewage Sludge, Pedologist, Vol. 54, pp 294-301, 2011.

14. Shahsavarzadeh-Jangi, P., Shojaosadati, S. A., Hashemi-Najafabadi, S. and Mousavi, S. M., Assesment of Bioavailability of Crude Oil in Three Different Agricultural Soils, Iranian Journal of Chemical Engineering, Vol. 12, No. 1, pp 3-12, 2015.

15. Chijioke-Osuji, C. C., Ibegbulam-Njoku, P. N. and Belford, E. J. D., Biodegradation of Crude Oil Polluted Soil by Co-Composting with Agricultural Wastes and Inorganic Fertilizer, Journal of Natural Sciences Research, Vol. 4, No. 6, pp 28-39, 2014.

16. Semple, K. T., Reid, B. J. and Fermor, T. R., Impact of Composting Strategies on the Treatment of Soils Contaminated with Organic Pollutants, Environmental Pollution, Vol. 112, No. 2, pp 269-283, 2011, https://doi.org/10.1016/S0269-7491(00)00099-3

17. Thapa, B., Ajay Kumar, K. C. and Ghimire, A., A Review on Bioremediation of Petroleum Hydrocarbon Contaminants in Soil, Kathmandu University Journal of Science, Engineering and Technology, Vol. 8, No. 1, pp 164-170, 2012, https://doi.org/10.3126/kuset.v8i1.6056 
18. Xu, Y. and Liu, M., Bioremediation of Crude Oil-Contaminated Soil: Comparison of Different Biostimulation and Bioaugmentation Treatments, J. Hazard. Mater., Vol. 183, No. 1-3, pp 395-401, 2010, https://doi.org/10.1016/j.jhazmat.2010.07.038

19. Omosiowho, U. E., Comparative Analysis of Composting and Landfarmingas Bioremediation Techinques in Hydrocarbon Degradation, Intl. J. Sci. Env. Tech., Vol. 3, No. 6, pp 1977-1995.

20. Qin, G., Gong, D. and Fan, M.-Y., Bioremediation of Petroleum-Contaminated Soil by Biostimulation Amended with Biochar, Intl. Biodeter. Biodeg., Vol. 85, pp 150-155, 2013, https://doi.org/10.1016/j.ibiod.2013.07.004

21. Margesin, F. and Schinner, F., Manual of Soil Analysis: Monitoring and Assessing Soil Bioremediation, Springer, Berlin, Germany, 2005.

22. Indonesian National Standard No. 03-1964, Standard Test Method for Particle-Size Analysis of Soils (in Indonesian), Department of National Standarization, Jakarta, Indonesia, 2000.

23. Zhang, Y., Zhu, Y., Houot, S., Qiao, M., Nunan, N. and Garnier, P., Remediation of Polycyclic Aromatic Hydrocarbon (PAH) Contaminated Soil Through Composting with Fresh Organic Wastes, Env. Sci. Poll. Res., Vol. 18, No. 9, pp 1574-1584, 2011, https://doi.org/10.1007/s11356-011-0521-5

24. Liang, C., Das, K. C. and McClendon, R. W., The Influence of Temperature and Moisture Contents Regimes on the Aerobic Microbial Activity of a Biosolids Composting Blend, Bioresources Technology, Vol. 86, No. 2, pp 131-137, 2003, https://doi.org/10.1016/S0960-8524(02)00153-0

25. Rynk, R., On-Farm Composting Handbook, North-east Regional Agricultural Engineering Service Pub. No. 54, Cooperative Extension Service, Ithaca, New York, USA, 1992.

26. Abraham, J., Organic Carbon Estimations in Soils: Analytical Protocols and their Implications, Rubber Sci., Vol. 26, pp 45-54, 2013.

27. Sparks, D. L., Methods of Soil Analysis (Part 3), Chemical Methods and Processes, Soil Science Society of America (SSSA) and American Society of Agronomy (ASA), Madison, Wisconsin, USA, 1996.

28. Olukunle, O. F., Characterization of Indigenous Microorganisms Associated with Crude Oil-Polluted Soils and Water Using Traditional Techniques, Microbiology Journal, Vol. 3, No. 1, pp 1-11, 2013, https://doi.org/10.3923/mj.2013.1.11

29. Balows, A., The Prokaryotes: A Handbook on the Biology of Bacteria: Ecophysiology, Isolation, Identification, Applications, Springer-Verlag, Heidelberg, Germany, 1992.

30. Holt, J. G., Kriey, N. R., Sneath, P. H. A. and Staley, J. T., Bergey's Manual of: Determinative Bacteriology ( $9^{\text {th }}$ ed.), Lippincott Williams and Wilkins, Baltimore, USA, 1994.

31. American Public Health Association - American Water Works Association - Water Environment Federation (APHA-AWWA-WEF), Standard Methods for the Examination of Water and Wastewater, American Public Health Association, Washington, D. C., USA, 2005.

32. ASTM D7066-04, Standard Test Method for Dimer/Trimer of Chlorotrifluoroethylene (S-316) Recoverable Oil and Grease and Nonpolar Material by Infrared Determination, ASTM International, West Conshohocken, Pennsylvania, USA, 2011.

33. Barje, F., El Fels, L., El Hajjouji, H., Amir, S., Winterton, P. and Hafidi, M., Molecular Behaviour of Humic Acid-Like Substances during Co-composting of Olive Mill Waste and the Organic Part of Municipal Solid Waste, International Biodeterioration \& Biodegradation, Vol. 74, pp 17-23, 2012, https://doi.org/10.1016/j.ibiod.2012.07.004

34. Antizar-Ladislao, B. and Russell, N. J., In-Vessel Composting as a Sustainable Bioremediation Technology of Contaminated Soils and Waste, Nova Science Publishers, Inc., Edinburgh, Scotland, 2007.

35. Winquist, E., The Potential of Ligninolytic Fungi in Bioremediation of Contaminated Soils, Ph.D. Thesis, Aalto University, Espoo, Finland, 2014. 
36. Tchobanoglous, G., Theisen, H. and Vigil, S. A., Integrated Solid Waste Management. Engineering Principles and Management Issue, McGraw Hill International Editions, New York, USA, 1993.

37. Crawford, S. I., Johnson, G. E. and Goetz, F. E., The Potential for Bioremediation of Soils Containing PAH By Composting, Compost Science and Utilization, Vol. 1, No. 3, pp 41-47, 1993, https://doi.org/10.1080/1065657X.1993.10757888

38. Kavitha, V., Mandal, A. B. and Gnanamani, A., Microbial Biosurfactant Mediated Removal and/or Solubilization of Crude Oil Contamination from Soil and Aqueous Phase: An Approach with Bacillus licheniformis MTCC 5514, International Biodeterioration \& Biodegradation, Vol. 94, pp 24-30, 2014, https://doi.org/10.1016/j.ibiod.2014.04.028

39. Gestel, K. V., Mergaert, J., Swings, J., Coosemans, J. and Ryckeboer, J., Bioremediation of Diesel Oil-Contaminated Soil by Composting by Biowaste, Environmental Pollution, Vol. 125, No. 3, pp 361-368, 2013, https://doi.org/10.1016/S0269-7491(03)00109-X

40. Quagliotto, P., Viscardi, G., Montoneri, E., Gobetto, R., Adani, F. and Tambone, F., Compost Humic Acid-Like Matter as Surfactant, Geophysical Research Abstracts, Vol. 7, 2005.

41. Mizwar, A., Sari, G. L., Juliastuti, S. R. and Trihadiningrum, Y., Bioremediation of Soil Contaminated with Native Polycyclic Aromatic Hydrocarbons from Unburnt Coal Using an In-Vessel Composting Method, Bioremediation Journal, Vol. 20, No. 2, pp 98-107, 2016, https://doi.org/10.1080/10889868.2015.1124064

42. Rhbal, H., Souabi, S., Safi, M., Terta, M., Arad, M., Anouzla, A. and Hafid, M., Soils Bioremediation of Hydrocarbons and Green Waste Elimination Through Composting Process, International Journal of Environmental Monitoring and Analysis, Vol. 2, No. 3, pp 13-22, 2014, https://doi.org/10.11648/j.ijema.s.20140203.13

43. Stanier, R. Y., Adelberg, E. A. and Ingraham, J. L., General Microbiology ( $5^{\text {th }}$ ed.), Palgrave Macmillan, London, UK, 1986.

44. Prakash, A., Bisht, S., Singh, J., Teotia, P., Kela, R. and Kumar, V., Biodegradation Potential of Petroleum Hydrocarbons by Bacteria and Mixed Bacterial Consortium Isolated from Contaminated Sites, Turkish J. Eng. Env. Sci., Vol. 38, pp 41-50, 2014.

45. Ni'matuzahroh, Trikurniadewi, N., Pramadita, A. R. A., Pratiwi, I. A., Salamun, Fatimah and Sumarsih, S., Biodegradation of Naphtalene and Phenanthrene by Bacillus subtilis 3KP, AIP Conference Proceeding, Vol. 1854, No. 1, pp 1-6, 2017, https://doi.org/10.1063/1.4985417

46. Cerqueira, V. S., Hollenbach, E. B., Maboni, F., Vainstein, M. H., Camargo, F. A. O., Peralba, M. C. and Bento, F. M., Biodegradation Potential of Oily Sludge by Pure and Mixed Bacterial Cultures, Bioresource Technology, Vol. 102, No. 23, pp 11003-11010, 2011, https://doi.org/10.1016/j.biortech.2011.09.074

47. Tuleva, B., Christova, N., Jordanov, B., Nikolova-Damyanova, B. and Petrov, P., Naphthalene Degradation and Biosurfactant Activity by Bacillus Cereus 28BN, Z. Naturforsch, Vol. 60, No. 7-8, pp 577-582, 2005.

48. Ole, M. A. N., Bioremediation of Benzene, Toluene and Xylene (BTX) from Petroleum Contaminated Soil by Aerobic Bacteria at Slurry Phase in Bioreactor (in Indonesian), Ph.D. Thesis, Sepuluh Nopember Institute of Technology, Surabaya, Indonesia, 2017.

49. Gupta, A., Joseph, B., Mani, A. and Thomas, G., Biosynthesis and Properties of an Extracellular Thermostable Serine Alkaline Protease from Virgibacillus Pantothenticus, World Journal of Microbiology and Biotechnology, Vol. 24, No. 2, pp 237-243, 2008, https://doi.org/10.1007/s11274-007-9462-z 